\title{
Perceived Value and Its Predictive Relationship with Satisfaction and Loyalty in Ecotourism: A Study in the Posets-Maladeta Natural Park in Spain
}

\author{
Conrado Carrascosa-López $^{1}$ (D), Mauricio Carvache-Franco ${ }^{2}$ iD and Wilmer Carvache-Franco $^{3, *(D)}$ \\ 1 Departamento Organización Empresas, Universitat Politècnica de València, 46022 Valencia, Spain; \\ concarlo@upvnet.upv.es \\ 2 Facultad de Turismo y Hotelería, Universidad Espíritu Santo, Samborondón 092301, Ecuador; \\ mauricio2714@hotmail.com \\ 3 Facultad de Ciencias Sociales y Humanísticas, Escuela Superior Politécnica del Litoral, ESPOL, \\ Guayaquil 09015863, Ecuador \\ * Correspondence: wcarvach@espol.edu.ec; Tel.: +593-9801-05090
}

Citation: Carrascosa-López, C.; Carvache-Franco, M.; Carvache-Franco, W. Perceived Value and Its Predictive Relationship with Satisfaction and Loyalty in

Ecotourism: A Study in the Posets-Maladeta Natural Park in Spain. Sustainability 2021, 13, 7860. https://doi.org/10.3390/su13147860

Academic Editors: Roberta Sisto, Giulio Mario Cappelletti, Edgardo Sica and Piervito Bianchi

Received: 2 June 2021

Accepted: 9 July 2021

Published: 14 July 2021

Publisher's Note: MDPI stays neutral with regard to jurisdictional claims in published maps and institutional affiliations.

Copyright: (c) 2021 by the authors. Licensee MDPI, Basel, Switzerland. This article is an open access article distributed under the terms and conditions of the Creative Commons Attribution (CC BY) license (https:// creativecommons.org/licenses/by/ $4.0 /)$.

\begin{abstract}
Ecotourism involves visiting natural areas to carry out environmentally friendly activities, contributing to environmental care. The present study aims to: (i) establish the dimensions of the perceived value in ecotourism applied to a natural park, (ii) analyze the dimensions of perceived value that predict ecotourism satisfaction, and (iii) identify the dimensions of perceived value that predict ecotourists' intentions to return, recommend, and provide positive word of mouth about the ecotourism destination as loyalty variables. The research was conducted in the PosetsMaladeta Natural Park in Spain. The sample taken in situ consisted of 341 questionnaires. For data analysis, factor analysis and the stepwise multiple regression method were used. The results showed three dimensions of perceived value: economic, functional, and social and emotional. The "functional" value was the most significant predictor of ecotourists' satisfaction, intentions to return, and to provide positive word of mouth. Likewise, the "functional" and the "social and emotional" dimensions were important predictors of tourists' intentions to recommend these places. These findings will serve as management guides for different institutions and tourism service providers of protected areas to develop products according to tourists' perceived value.
\end{abstract}

Keywords: ecotourism; perceived value; satisfaction; loyalty; protected area

\section{Introduction}

Ecotourism development is a distinct market phenomenon and a necessary form of sustainable tourism [1], which grows three times faster than tourism in general [2]. Ecotourism's rising popularity worldwide has encouraged tourist destinations to receive more and more tourists who like contact with nature and are willing to comply with the protection standards of the natural area chosen [3]. Therefore, over the last two decades of ecotourism growth, sustainable environmental development has become a matter of serious concern $[4,5]$. This is because the steady increase in the flows of national and international tourists that destinations receive each year can lead to significant changes in ecosystems [6]. Under these conditions, for tourism activity to be maintained sustainably, preventive or remediable measures, where appropriate, must be considered to avoid a greater negative impact $[7,8]$.

Ecotourism comprises contact with nature, culture, agriculture, wildlife, and adventure activities $[9,10]$. Since the United Nations designated 2002 as the "International Year of Ecotourism," a large number of tour operators use "ecotourism" as their identity label in the tourism market niche [11]. Ecotourism provides a solution for sustainable social, economic, and environmental development and promotes natural and cultural diversity [12]. From this perspective, community ecotourism has focused not only on 
protecting the environment but also on preserving the culture to improve the well-being of the local population [13-15]. For Ketema [16], ecotourism should become a gateway for rural communities' economic development. In this sense, destinations whose tourist offer is based mainly on natural resources have to face significant challenges to maintain their sustainability due to the increase of travelers attracted to nature and places perceived as ecologically responsible, which puts a strain on these sites' environment [17].

Visitor behavior in protected areas is related to perceived value, which can be conceptualized as the personal evaluation of travel products such as service, quality, price, emotions, and social factors [18]. It is a construct formed by the differences between the benefits received (economic, social, and relationships) and sacrifices made (price, time, effort, risk, and convenience) by the consumer $[19,20]$. Perceived value has been widely used to analyze and understand tourists' future behavior concerning purchase decisions [21]. For example, scholars have explored adventure tourism [22], festivals [23], scuba diving tourism [24], and tourism gentrification [25].

Perceived value has been considered a reliable concept to anticipate tourist behavior $[26,27]$. It relies on the tourist's evaluation of the information received before purchasing, the quality of the services, tourist resources, surrounding nature, time, money, and effort invested [21]. Furthermore, the emphasis on perceived value provides a good foundation for attracting responsible tourists who share common values [28]. Thus, the measurement of perceived value can have far-reaching implications for the tourism field [29].

Within this framework, the Posets-Maladeta Natural Park in Spain is a protected natural area located north of the La Ribagorza region and northeast of the Sobrarbe region. Within its limits are the two highest altitude massifs in the Pyrenees: the Posets or Llardana massif and the Maladetas massif. With more than $70 \%$ of the park's total surface $(33,440 \mathrm{ha})$ above $1800 \mathrm{~m}$ of altitude, the main interest in this natural space lies in the high mountain landscapes and glacier modeling (valleys, lakes, ridges, and other forms of the landscape). Furthermore, some of the largest glaciers in the Pyrenees, such as the Aneto glacier, are found within the park. This set of perpetual ice is part of the Natural Monument of the Pyrenean Glaciers. Therefore, this remarkable natural park is ideal for ecotourism activities, both skiing in winter and enjoying nature in summer, being one of the most visited areas of all the Pyrenees and an important source of income for this region.

In this regard, it is crucial to know the dimensions of the perceived value in ecotourism applied to natural parks and how these dimensions predict the future behavior of ecotourists to prepare sustainable development plans in protected areas and offer products that address the demand. However, despite the importance of the perceived value in ecotourism as a multidimensional construct, few studies in the academic literature have documented the relationship of perceived value with the satisfaction and loyalty of ecotourism demand in natural parks. In light of this research gap, the present study aims to: (i) establish the dimensions of the perceived value in ecotourism applied to a natural park; (ii) analyze the dimensions of perceived value that predict ecotourism satisfaction, and (iii) identify the dimensions of perceived value that predict ecotourists' intentions to return, recommend, and provide positive word of mouth about the ecotourism destination, as loyalty variables.

This research's findings and theoretical implications may serve as management guides for protected areas since demand studies are essential for elaborating sustainable development plans.

\section{Literature Review}

\subsection{Perceived Value in Tourism}

For several academics, perceived value is primarily based on a utilitarian perspective, whereby economic and cognitive appraisals are used to examine the trade-off between costs and benefits/quality [30]. However, other authors such as Chi and Kilduff [31], Koller et al. [32], and Lee et al. [23] argue that a practical perspective is too narrow and simplistic to encompass holistic representations of the perception of value as an intrinsic 
dimension. Therefore, it is recommended to base perceived value on a multidimensional construct, embracing emotional, social, hedonic, and utilitarian dimensions that critically build positive emotions and customer satisfaction [23].

Previous studies on perceived value have been documented in the tourism field. For example, Williams and Soutar [22] found five dimensions of perceived value in Australian adventure tourism: value for money, functional, emotional, social, and novelty values. They established that all these dimensions significantly influenced tourist satisfaction. Similarly, Lee et al. [23] identified emotional and functional values as contributors to satisfaction and behavioral intentions. In the same perspective, Lee et al. [33] examined the underlying factors affecting perceived value among South Korean tourists visiting the Mount Kumgang complex in North Korea. Their results showed emotional, functional, and economic values as central elements directly affecting guest satisfaction, which influenced the intentions to recommend and revisit the destination.

Furthermore, Schoeman et al. [24] studied the perceived value of a diving experience in Sodwana Bay, South Africa. They identified five perceived values: emotional, risk, functional, social, and epistemic. The epistemic value was rated as the most important for divers in marine tourism. Similarly, Um and Yoon [25] investigated tourists' perceived value of the gentrification experience in three areas of South Korea affected by tourism gentrification: Seo-chon, the Hongik University area, and Jeju island. They identified three perceived values: conditional, epistemic, and functional. In addition, they found that visitors' perceived value of the experience influenced their responsible tourism attitudes and intentions.

\subsection{Perceived Value in Ecotourism}

Several previous studies have analyzed perceived value in ecotourism. For example, Jamal et al. [34], in community-based research, established five dimensions of perceived value in Malaysia: functional (establishment), functional (price), experimental (host-guest interaction), experiential (activity, culture, and knowledge), and emotional. Similarly, Kim and Park [28] analyzed community ecotourism in South Korea based on twelve variables and found four dimensions of perceived value: economic, functional, emotional, and social. They demonstrated that functional, social, and emotional values had positive effects on general satisfaction. In another ecotourism study, Kim and Thapa [35] found four perceived values on Jeju Island in South Korea: quality, emotional, price, and social. The authors claimed that perceived quality, emotional and social values significantly affected flow experience and satisfaction. In addition, the flow experience was significantly and positively related to satisfaction, environmentally responsible behaviors, and loyalty to the destination.

Furthermore, Carvache-Franco et al. [36] identified four perceived values in Ecuadorian protected areas: economic, functional, emotional, and social. The authors found that the functional and emotional values were related to satisfaction and loyalty. In another study, Carvache-Franco et al. [37] established three dimensions of perceived value in Costa Rican protected areas: economic-functional, emotional, and social. They found that the economic-functional value greatly influenced general satisfaction and that the emotional value was the most significant predictor of tourists' intention to return, recommend, and provide positive word of mouth about the ecotourism destination.

Previous findings in Malaysia, South Korea, Ecuador, and Costa Rica described different dimensions and several concurrent ones such as economic, functional, emotional, and social. The variety of dimensions of the perceived value in ecotourism encourages our first research question: RQ1. What are the dimensions of the perceived value in ecotourism applied to a natural park?

\subsection{Perceived Value in Satisfaction and Loyalty}

Regarding the effects of perceived value on tourist satisfaction, Lee et al. [38] divided perceived value into functional, general, and emotional and tested its impact on tourist 
satisfaction in South Korea. They found that all three values positively influenced tourist satisfaction. Ha and Jang [39] considered the hedonic and utilitarian value in dining experiences in Korean restaurants in the United States. They found that both values were positively related to satisfaction. In another study, Lee et al. [23] established that functional and emotional values were positively associated with tourist satisfaction.

Regarding the effects of perceived value on satisfaction and loyalty, Peña et al. [40] examined the relationships between perceived value, satisfaction, and loyalty in rural tourism in Spain. The results revealed that perceived value positively affected tourist satisfaction and loyalty. Furthermore, Jin et al. [41] identified that the perceived value and image of the park exerted a direct influence on customer satisfaction and positively affected the behavioral intentions in South Korea. In another study, Oviedo-García et al. [42] established that the perceived value of an ecotourism site and attitudes toward ecotourism fully mediated the influence of ecotourism knowledge on ecotourism satisfaction. Therefore, ecotourism awareness would positively affect ecotourism satisfaction when the ecotourism site has a high perceived value and positive attitudes toward ecotourism.

Kim and Park study [28] demonstrated that functional, social, and emotional values positively influenced general satisfaction. In addition, overall satisfaction and tourism satisfaction were significant antecedents of destination loyalty. Similarly, Kim and Thapa [35] examined tourists' perceived values (quality, emotional, price, and social) and found that the perceived quality, emotional and social values significantly affected their flow experience and satisfaction. Moreover, the flow experience was significantly and positively related to satisfaction, environmentally responsible behaviors, and loyalty to the destination. In another study, Carvache-Franco et al. [36] identified four perceived values in Ecuador: economic, functional, emotional, and social. They found that the functional and emotional values were related to satisfaction and loyalty. Finally, for Li. [43], the perceived value had a significant positive impact on the satisfaction and confidence of the tourism brand.

In summary, previous research has shown that perceived value leads to favorable outcomes in terms of satisfaction and behavioral intentions [44,45]. In fact, future consumer behavior is the product of the perceived value of each tourist experience [18]. Also, several researchers confirm the importance of consumer loyalty in tourism [46-48]. In this sense, perceived value has been considered a predictor of visitors' intentions [26], directly influencing tourist loyalty $[49,50]$. Literature has shown that perceived value affects tourist satisfaction and loyalty in protected areas. However, only a few studies have found concurrent dimensions of perceived value, such as social and emotional, to predict satisfaction and loyalty. The fact that studies on this subject are still scarce raises our second and third research question: RQ2. What are the dimensions of perceived value that predict satisfaction in ecotourism?; RQ3. What dimensions of perceived value predict ecotourists' intentions to return, recommend, and provide positive word of mouth about the ecotourism destination as loyalty variables?

\section{Methodology}

\subsection{Study Area}

The Posets-Maladeta Natural Park in Spain is located in the center of the Pyrenees Mountains range. It was named after its two massifs, the Posets massif and the Maladeta massif, with two of the highest peaks in the Pyrenees, the Posets $(3375 \mathrm{~m})$ and the Aneto (3404 m). It has 33,440 ha, protected by a peripheral area of 5290 ha, and belongs to several municipalities: Benasque, Sahún, Gistaín, San Juan de Plan, and Montanuy. This area was declared a Natural Park in 1994. It is one of the few natural parks with a Q certification for tourism quality, which guarantees an optimal quality in its tourist facilities and visitor services. This system refers to the equipment and services for public use offered by the parks, either directly or through concessionaires.

Its nature is very diverse due to the variety of heights. The park is at elevations from $1500 \mathrm{~m}$. in the valley to over $3404 \mathrm{~m}$. on the highest mountain, Mount Aneto. Among 
its flora, cotton grass (Eriophorum) and carnivorous plants such as the flytrap (Dionaea muscipula) or sundew (Drosera) stand out. In the lower and higher levels, birches (Betula) and hazelnuts (Corylus), and black pines (Pinus nigra) are found, respectively. In the humid areas, pines (Pinus), firs (Abies), and beech trees (Fagus) abound. Its fauna is also very varied, including wild boars (Sus scrofa), Pyrenean ibexes (Capra pyrenaica pyrenaica), white partridges (Lagopus muta), bearded vultures (Gypaetus barbatus), golden eagles (Aquila chrysaetos), and some protected species such as the owl (Strigiformes) or grouse (Tetraoninae).

Its landscapes originated from the quaternary glaciers that carved U-shaped valleys during the ice age. However, they have been regressing from then until now, and many have disappeared throughout the Pyrenees. The Posets Maladeta Natural Park preserves the last remains of these glaciers. They are the southernmost glaciers in Europe and are protected by the Pyrenean Glaciers Natural Monuments. As a result of the retreat of the glaciers, many mountain lakes of glacial origin are found, known as ibones. Currently, its valleys are crossed by several rivers: the Ésera, the Cinqueta, and the Noguera Ribagorzana, among the most important.

The Natural Park organizes numerous ecotourism activities, such as conferences, workshops, guided tours, movies, and courses for children and adults. These activities are planned by its four interpretation centers, Benasque, Eriste, Aneto, and San Juan de Plan [51] (See Figure 1).
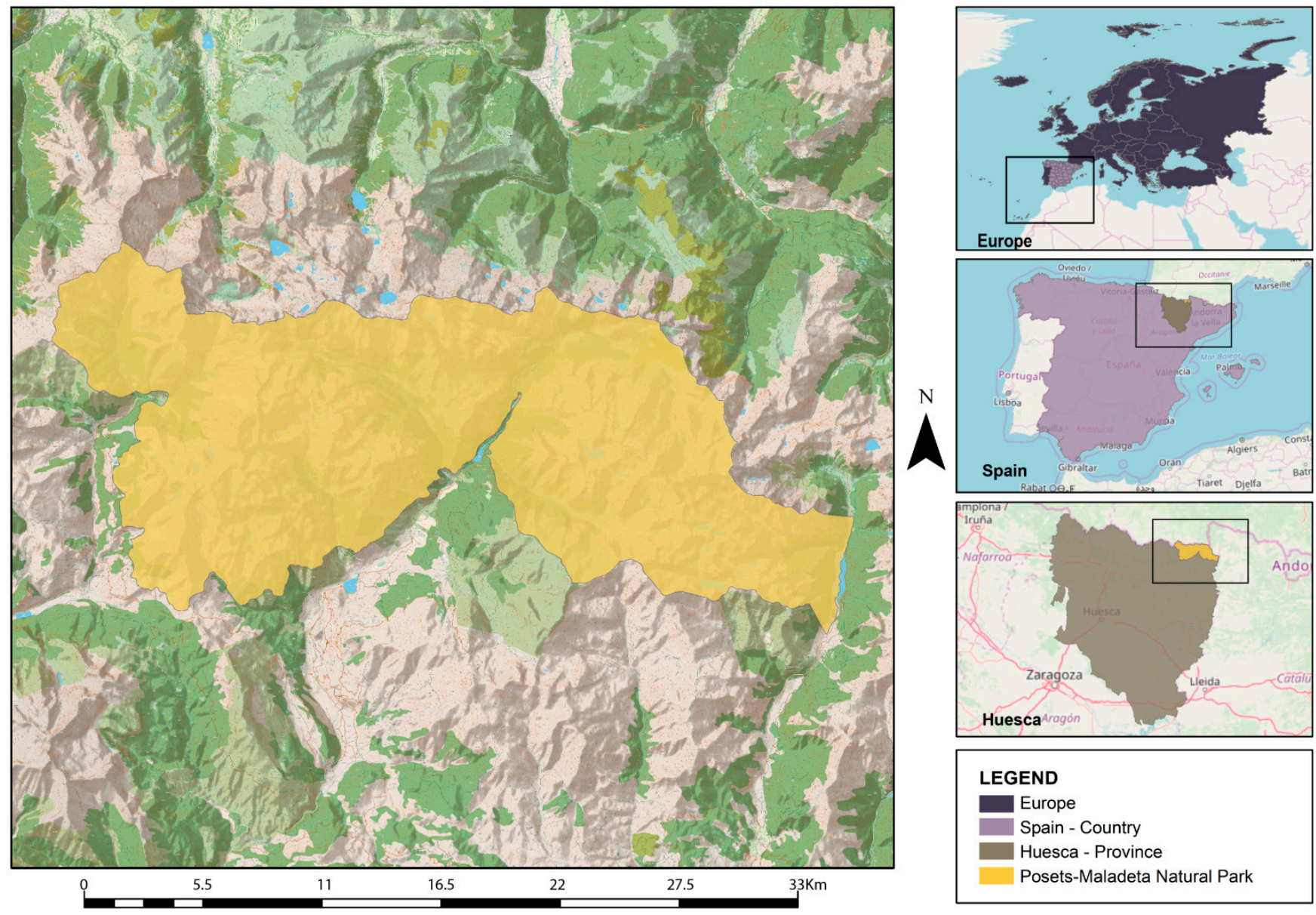

Figure 1. Geographical location of the Natural Park of Posets-Maladeta, Spain. GIS Layer Source: National Geographic Information Center, Spain. 


\subsection{Survey, Data Collection, and Analysis}

To achieve the objectives of the present study, a three-section questionnaire was prepared. The first part dealt with the sociodemographic information of the respondents with questions related to age, gender, education, professional activity, visit frequency, travel companions, and travel expenses. This section was adapted from the study by Lee et al. [52] and was measured with closed-ended questions, and the possible answers were based on each topic consulted. The second section measured the perceived value through 12 items, adapted from Kim and Park's research [28], measured on a five-point Likert scale, ranging from 1 (in disagreement) to 5 (strong agreement). The answers were scored using this scale in a range of values according to the respondents' degree of agreement. Finally, the third part explored the satisfaction and loyalty of the visitors and was also adapted from Kim and Park's study [28]. Satisfaction was measured on a 5-point Likert scale, ranging from 1 (very dissatisfied) to 5 (very satisfied). In this part, the general satisfaction of the visit to the Natural Park was consulted. Tourist loyalty was also measured on a five-point Likert scale, ranging from 1 (unlikely) to 5 (very likely). This part contained three items about returning, recommending, and providing positive word of mouth about the protected area.

Five experts confirmed the validity of the questionnaire. They evaluated its items and contributed to its construction. Moreover, the conceptual equivalence was assessed by verifying the words and their appropriate meaning according to the context. The experiential equivalence was also evaluated, ensuring that the elements reflected the experience of the visitors. The semantic equivalence was verified to assure that the words had only one meaning. Furthermore, to validate the questionnaire, a pilot test of 15 surveys was carried out, and several elements of the questionnaire questions were improved. The Cronbach's Alpha index of the perceived value scale was used to analyze the reliability of the questionnaire. It reached a value greater than 0.7 , indicating good internal consistency among the scale items.

The questions were carefully designed to minimize biases. Hence, the researchers avoided technical or difficult questions, and they used words with a precise meaning according to the profile of the visitors taking part in the sample. The questions and options were randomly rearranged. In addition, the questions were written to assure unbiased, neutral, or equally acceptable options for the topics of the study.

The causal research method was used to find the relationships between the independent variables (perceived value) and the dependent variables (satisfaction and loyalty). This was useful to identify the effect that the variable "perceived value" had on the variables "visitor satisfaction and loyalty." The survey was used as an information-gathering technique. It allowed collecting information easily and timely and obtaining specific (closed) answers about a representative group of the population. Convenience sampling was used to collect the sample. It is a technique where the researcher chooses the sample members because of their proximity, availability of time to answer and fill out the questionnaires, and willingness to participate in the study. This type of sampling was also used due to the large study population.

The sample was obtained from national and foreign tourists visiting the PosetsMaladeta Natural Park. The surveys were applied during August and September 2019 to visitors over 18 years of age. The interviewers approached the visitors and explained the purpose of the survey. No personal information was requested. If they agreed to fill it out voluntarily, the questionnaire was given to them. The survey was administered by researchers from the Polytechnic University of Valencia, who were attentive to clarify any doubts or concerns while the respondents independently answered the questions. The interviewers made sure to correctly balance the respondents belonging to the sociodemographic profiles (gender, age, level of education, and professional activity).

Sample collection took place at "La Besurta," a rest area with picnic tables within the natural park, next to a bus stop and near one of the entrances' car park. It is a crossroad that offers different hiking types, from the riskiest, such as the ascent to the highest peaks, to simple hikes for families with small children. The park authorities were asked for 
permission to administer the surveys and did not require any written consent, nor was the ethics committee's approval necessary. However, in the header of the questionnaire, the sample consent was included.

Data were collected on several days during the three months and at different times of the day at "La Besurta," from 11:00 to 20:00, to minimize biases. This process allowed to obtain data from a diverse number of tourists who visited this Posets-Maladeta Natural Park at different times and days of the week. Furthermore, the weather conditions were good on those days, which favored data collection and facilitated the visit of more people to the park.

The researchers used the infinite population formula because the study population exceeded 100,000 people. Thus, 341 valid questionnaires were obtained as the sample size. The variability of the population was estimated at $50 \%(p=q=0.5)$. The margin of error was $+/-5 \%$, and the confidence level $95 \%$. The collected data were organized, tabulated, and statistically analyzed using the IBM SPSS program, version 22.0 for Windows. The data were examined in two stages to obtain the results. First, factor analysis reduced the items to few factors. In addition, the factor analysis was carried out to identify the constructs underlying the variables, providing an overview of the most important dimensions. Specifically, a Varimax rotation was used to minimize the number of variables with high loads on each factor. This simplified the interpretation of the data.

The Kaiser criterion was used to find the number of factors retaining eigenvalues greater than 1 . These eigenvalues indicate that the factor manages to explain more variance than an item by itself. The Kaiser-Meyer-Olkin (KMO) index was greater than 0.7, so it was appropriate to perform the factor analysis. Bartlett's test was significant $(p<0.05)$, and it was possible to apply the Factor Analysis model. In the second stage, a multiple regression using the enter method was used to select the dimensions of perceived value predicting satisfaction and future behavior variables. This regression method only included the significantly related variables $(p<0.05)$.

\section{Results}

\subsection{Sociodemographic Aspects and Characteristics of the Trip}

The sample was composed of $57.5 \%$ male and $42.5 \%$ female respondents. The majority were between 10 and 49 years old (29.9\%), followed by those between 30 and 39 (21.1\%). Most were college (46.9\%) and high school graduates $(25.5 \%)$. They were predominantly private employees (34.3\%) and public employees (21.4\%). Most of them traveled in groups of 3 to 6 people (57.8\%). The majority visited the Natural Park annually $(40.5 \%)$ and wanted to spend from 20 to 40 Euros on their visit to the protected area. Table 1 presents the results.

Table 1. Sociodemographic aspects and characteristics of the trip.

\begin{tabular}{|c|c|c|c|}
\hline Demographics & Categories & $\mathrm{N}=341$ & $\%$ \\
\hline \multirow{2}{*}{ Gender } & Male & 196 & 57.5 \\
\hline & Female & 145 & 42.5 \\
\hline \multirow{6}{*}{ Age } & $<20$ years old & 30 & 8.8 \\
\hline & 20 to 29 years & 50 & 14.7 \\
\hline & 30 to 39 years & 72 & 21.1 \\
\hline & 40 to 49 years & 102 & 29.9 \\
\hline & 50 to 59 years & 58 & 17.0 \\
\hline & $>59$ years old & 29 & 8.5 \\
\hline \multirow{4}{*}{ Level of education } & Primary & 9 & 2.6 \\
\hline & High school & 87 & 25.5 \\
\hline & Academic & 160 & 46.9 \\
\hline & Postgraduate/Master/Ph. D & 85 & 24.9 \\
\hline
\end{tabular}


Table 1. Cont.

\begin{tabular}{|c|c|c|c|}
\hline Demographics & Categories & $\mathrm{N}=341$ & $\%$ \\
\hline \multirow{10}{*}{ Professional activity } & Student & 47 & 13.8 \\
\hline & Researcher/Scientist & 19 & 5.6 \\
\hline & Entrepreneur/Business Owner & 21 & 6.2 \\
\hline & Private employee & 117 & 34.3 \\
\hline & Public employee & 73 & 21.4 \\
\hline & Housework & 4 & 1.2 \\
\hline & Unemployed & 6 & 1.8 \\
\hline & Retired & 15 & 4.4 \\
\hline & Autonomous & 28 & 8.2 \\
\hline & Others & 11 & 3.2 \\
\hline \multirow{5}{*}{ Travel frequency } & Annually & 138 & 40.5 \\
\hline & Every 6 months & 78 & 22.9 \\
\hline & Every 3 months & 68 & 19.9 \\
\hline & Monthly & 38 & 11.1 \\
\hline & Weekly & 19 & 5.6 \\
\hline \multirow{3}{*}{$\begin{array}{l}\text { Group of people visiting the } \\
\text { protected area }\end{array}$} & Less than 3 people & 99 & 29.0 \\
\hline & 3-6 people & 197 & 57.8 \\
\hline & More than 6 people & 45 & 13.2 \\
\hline \multirow{6}{*}{ Average spending per person } & Less than $€ 20$ & 77 & 22.6 \\
\hline & $€ 20-€ 40$ & 125 & 36.7 \\
\hline & $€ 40-€ 60$ & 64 & 18.8 \\
\hline & $€ 60-€ 80$ & 33 & 9.7 \\
\hline & $€ 80-€ 100$ & 28 & 8.2 \\
\hline & More than $€ 100$ & 14 & 4.1 \\
\hline
\end{tabular}

\subsection{Dimensions of Perceived Value (Factor Analysis)}

A factor analysis was carried out to reduce the items into a smaller number of factors and facilitate the interpretation of the results. The principal component analysis and the Varimax rotation method were used. Three factors were obtained using the Kaiser criterion, representing $58.56 \%$ of the total variance. The KMO index (Kaiser-Meyer-Olkin) was 0.78 , so the data were adjusted to a factor analysis model. In addition, the Barlett test of sphericity was significant $<0.05$; therefore, factor analysis had to be applied. Finally, Cronbach's Alpha of all items was 0.80 , indicating a high internal consistency among the scale elements. Table 2 shows the results.

Table 2. Dimensions of perceived value (factor analysis).

\begin{tabular}{|c|c|c|c|c|}
\hline Factor & Loading Factor & Eigen-Value & Variance Explained & Cronbach's a \\
\hline Economic value & & 4199 & 34,989 & 0.834 \\
\hline The destination has reasonable prices & 0.901 & & & \\
\hline The destination is cheap & 0.836 & & & \\
\hline The destination has good value for money & 0.811 & & & \\
\hline The destination has an acceptable level of quality & 0.559 & & & \\
\hline Functional value & & 1536 & 12,799 & 0.657 \\
\hline This visit is calm and pleasant & 0.777 & & & \\
\hline The number of visitors the area receives is adequate & 0.727 & & & \\
\hline The destination is well organized & 0.601 & & & \\
\hline The destination is convenient for me & 0.524 & & & \\
\hline Social and emotional value & & 1293 & 10,774 & 0.639 \\
\hline I feel like a special person & 0.785 & & & \\
\hline This area is visited by many people I know & 0.731 & & & \\
\hline It is an exciting destination & 0.607 & & & \\
\hline People are friendly and make you feel at home & 0.497 & & & \\
\hline Total variance extracted $(\%)$ & & & 58,562 & \\
\hline Cronbach's Alpha of all items & & & & 0.801 \\
\hline
\end{tabular}


As seen in Table 2, the first factor was called "Economic value," which had the highest explanatory power, $34.99 \%$ of the total variance. This dimension was related to tourists' perception of products and services at reasonable prices and a good relationship between prices and quality. The second factor was called "Functional value" and obtained $12.80 \%$ of the total variance. This was related to the value that tourists perceive for well-organized and efficient products and services. Finally, the third factor was called "Social and emotional value" and comprised $10.77 \%$ of the total variance.

The perceived values of ecotourism obtained were economic value, functional value, and social and emotional value. This evidence responds to our first research question: RQ1. What are the dimensions of the perceived value in ecotourism applied to a natural park?

\subsection{Perceived Value and Overall Satisfaction}

The stepwise multiple regression method was used to analyze the dimensions of perceived value that predict general satisfaction at the destination. The regression modeling method used included all the variables at once (enter). An attempt was made to include some covariates to the model (gender, age, and level of education), but these were not significant since they did not contribute to the dependent variable "satisfaction," so they were not finally included in the model. Table 3 presents the results.

Table 3. Relationship between perceived value and satisfaction.

\begin{tabular}{lcccc}
\hline Variable & Beta & $\mathbf{t}$ & Sig. & Tolerance \\
\hline Economic & 0.114 & 2.273 & 0.024 & 1.000 \\
Functional & 0.371 & 7.425 & 0.000 & 1.000 \\
Social and emotional & 0.082 & 1.638 & 0.102 & 1.000 \\
(Constant) & & 167.602 & 0.000 & \\
\hline F & 20.995 & & & \\
Sig. & 0.000 & & & \\
Durbin-Watson & 1.750 & & & \\
\hline
\end{tabular}

According to Table 3 , the model presented a significant $\mathrm{F}$ test $(p<0.05)$, indicating a real relationship between the significant predictors (perceived value) and the response variable (satisfaction). The tolerance values showed no multicollinearity between the independent variables (tolerance close to or equal to 1). The Durbin-Watson statistic was 1.99, so it could be assumed that there was no autocorrelation in the errors. The results indicated that the "functional" dimension was the most significant predictor of tourists' general satisfaction in this protected area (Beta $=0.371, p<0.05$ ). This means that tourists feel more satisfied with products that are well organized and efficient. The second significant element was the "economic" factor (Beta $=0.144, p<0.05$ ). While the variable "social and emotional" was not significant $(p<0.05)$, so it did not contribute to the model.

Functional value was the most important predictor of satisfaction in ecotourism, which responds to our second research question: RQ2. What are the dimensions of perceived value that predict satisfaction in ecotourism?

\subsection{Perceived Value and Intentions to Return to the Protected Areas}

The dimensions of perceived value that predict tourists' revisit intention to this protected area were analyzed through multiple regression using the enter method. An attempt was made to include the covariates previously mentioned, but these did not contribute to the model. Table 4 shows the results. 
Table 4. Relationship between perceived value and return intentions.

\begin{tabular}{lcccc}
\hline Variable & Beta & $\mathbf{t}$ & Sig. & Tolerance \\
\hline Economic & 0.071 & 1.350 & 0.178 & 1.000 \\
Functional & 0.223 & 4.273 & 0.000 & 1.000 \\
Social and emotional & 0.156 & 2.990 & 0.003 & 1.000 \\
(Constant) & & 136.723 & 0.000 & \\
\hline F & 9.674 & & & \\
Sig. & 0.000 & & & \\
Durbin-Watson & 1.890 & & & \\
\hline
\end{tabular}

As shown in Table 4 , the model presented a significant $\mathrm{F}$ test $(p<0.05)$, indicating a real relationship between the significant predictors and the response variable (return). The tolerance values showed no multicollinearity between the independent variables. Furthermore, according to the Durbin-Watson statistic, it could be assumed that there was no autocorrelation in the errors. The results showed the "functional" dimension as the most significant predictor of tourists' intentions to return to this protected area (Beta $=0.223$, $p<0.05)$. The second most significant element was the "social and emotional" dimension (Beta $=0.156, p<0.05$ ). On the other hand, the variable "economic" was not significant; therefore, not a predictor of the intentions to return to the protected area.

\subsection{The Perceived Value and Intentions of Recommending Protected Areas}

The dimensions of perceived value that predict intentions to recommend this destination were analyzed through a multiple regression using the enter method. An attempt was made to include the covariates mentioned above, but these were not significant for the model. Table 5 presents the results.

Table 5. Relationship between perceived value and intentions to recommend.

\begin{tabular}{lcccc}
\hline Variable & Beta & $\mathbf{t}$ & Sig. & Tolerance \\
\hline Economic & 0.074 & 1.419 & 0.157 & 1.000 \\
Functional & 0.201 & 3.865 & 0.000 & 1.000 \\
Social and emotional & 0.201 & 3.869 & 0.000 & 1.000 \\
(Constant) & & 150.192 & 0.000 & \\
\hline F & 10.640 & & & \\
Sig. & 0.000 & & & \\
Durbin-Watson & 1.725 & & & \\
\hline
\end{tabular}

According to Table 5, the model presented a significant F test $(p<0.05)$. The tolerance values indicated no multicollinearity between the independent variables. Furthermore, it could be assumed that there was no autocorrelation in the errors (Durbin-Watson statistic). The results showed that two dimensions equally influenced the intentions to recommend this destination, the "Functional" with (Beta $=0.201, p<0.05)$ and the "Social and emotional" with (Beta $=0.201, p<0.05)$. Because the variable "economic" was not significant, therefore, not a predictor of the intentions to recommend this place.

This means that it is important for tourists to experience exciting situations and socially interact in these destinations to recommend such places to friends or acquaintances.

\subsection{Perceived Value and Positive Word of Mouth about the Destination}

The dimensions of the perceived value that predict the intentions to provide positive word of mouth about this protected area were analyzed through multiple regression using the enter method. An attempt was made to include the covariates mentioned, but these did not contribute to the model. Table 6 shows the results. 
Table 6. Relationship between perceived value and positive word of mouth about the destination.

\begin{tabular}{lcccc}
\hline Variable & Beta & $\mathbf{t}$ & Sg. & Tolerance \\
\hline Economic & 0.145 & 2.865 & 0.004 & 1.000 \\
Functional & 0.301 & 5.952 & 0.000 & 1.000 \\
Social and emotional & 0.154 & 3.037 & 0.003 & 1.000 \\
(Constant) & & 205.870 & 0.000 & \\
\hline F & 17.620 & & & \\
Sig. & 0.000 & & & \\
Durbin-Watson & 1.882 & & & \\
\hline
\end{tabular}

According to Table 6 , the model presented a significant $\mathrm{F}$ test $(p<0.05)$. The tolerance values indicated no multicollinearity between the independent variables. Furthermore, according to the Durbin-Watson statistic, it could be assumed that there was no autocorrelation in the errors. The results showed that the "functional" dimension was the most significant predictor of tourists' intentions to provide positive word of mouth about this protected area (Beta $=0.301, p<0.05)$. The second most significant element was the "social and emotional" factor (Beta $=0.154, p<0.05$ ) and the third was the "economic" dimension with (Beta $=0.145, p<0.05)$.

This means that tourists will provide positive word of mouth about the destination if they find well-organized and efficient products and services. It also suggests that visitors seek a good social and emotional environment to interact with other tourists and local inhabitants, where quality products or services are offered reasonably.

These results answer our third research question: RQ3. What are the dimensions of the perceived value that predict ecotourists' intentions to return, recommend, and provide positive word of mouth about the ecotourism destination as loyalty variables? First, the "functional" value was the most important predictor of return. Second, the "social and emotional" value was the most salient predictor of visitors' intentions to recommend the destination. Finally, the "functional value" was the primary dimension predicting tourists" intentions to provide positive word of mouth about the destination, all of them as variables of ecotourist loyalty.

Figure 2 shows the results of the proposed model about the perceived value in ecotourism.
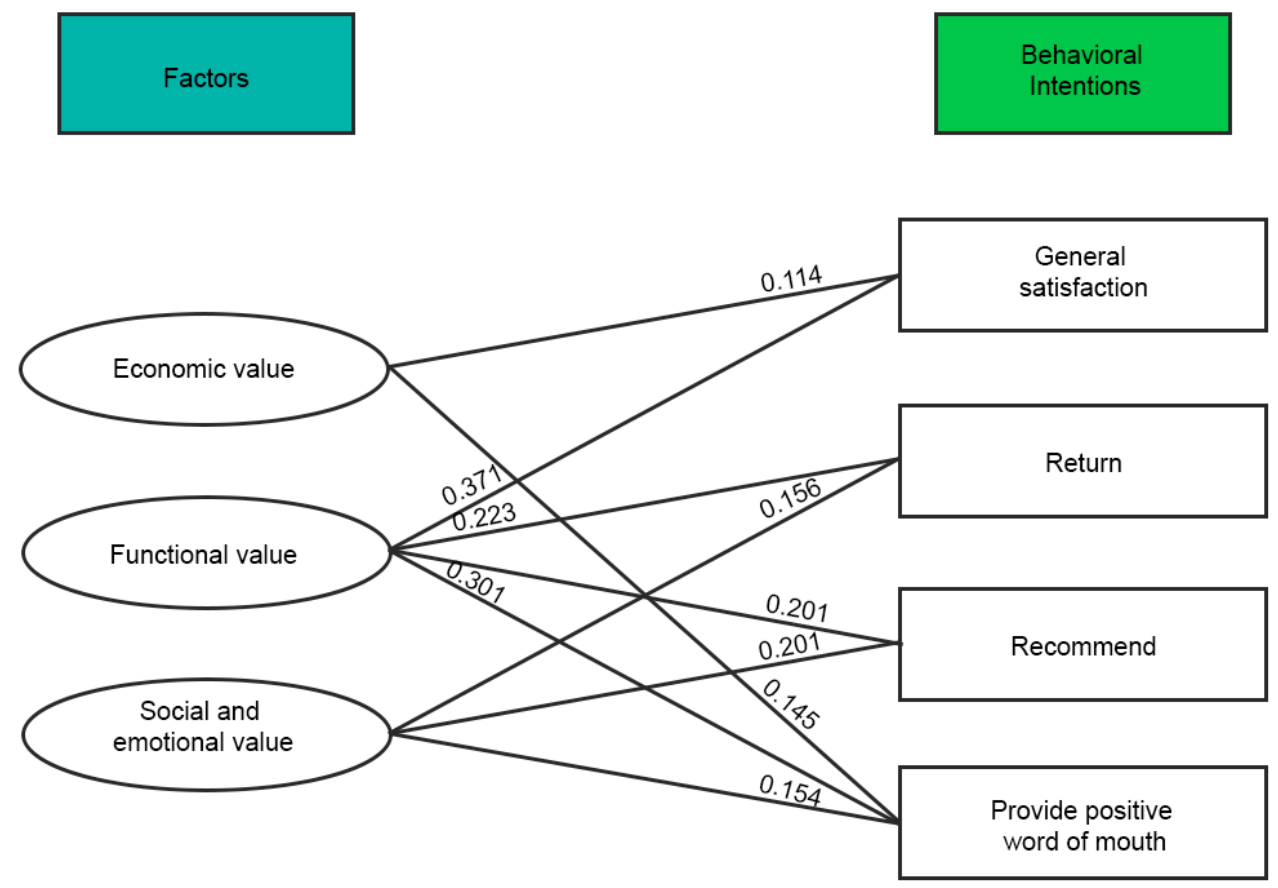

Figure 2. The perceived value in ecotourism as a predictor of behavior. 
As shown in Figure 2, the model presents three dimensions of the perceived value in ecotourism destinations, namely, economic, functional, and social and emotional. These three dimensions predict future behavior for visiting protected areas. The "functional" dimension is the most important predictor of satisfaction, return, and positive word of mouth. The "functional" and "social and emotional" dimensions are the most salient predictors of tourists' recommendation of these natural sites.

\section{Discussion}

The first objective of the present study aimed to establish the dimensions of the perceived value in ecotourism applied to a natural park. Thus, three dimensions of perceived value in ecotourism were found: economic, functional, and social and emotional. These findings are in line with the previous literature. The "functional and emotional" values identified by Lee et al. [38] and Lee et al. [23] coincide with our results. However, Lee et al. [23] did not establish the social and emotional value found in this research. In another study, Williams, and Soutar [22] identified value for money, functional and emotional, social, and novelty values, similar to those found in this research. Moreover, Jamal et al. [34] established five dimensions of perceived value: functional (establishment), functional (price), emotional, experimental (host-host interaction), and experiential (activity, culture, and knowledge), consistent with our findings.

In other research, Bajs [27] found functional and affective and social values, similar to our "functional" and "social and emotional" values, respectively. Additionally, Kim and Thapa [35] identified price, quality and emotional, and social perceived values, aligning with our functional, economic, and social and emotional dimensions. Finally, in more similar studies, Carvache Franco et al. [36] and Kim and Park [28] established four perceived values: economic, functional, emotional, and social. Although most of these values coincide with our results (functional, economic, and social and emotional), our research found the "social and emotional value" together as one dimension.

This study contributes to the literature in several ways. First, by adding three perceived values in ecotourism to the research on this area. Second, by finding the social and emotional values into a single dimension called "social and emotional value." This means that visitors experience emotions with a social component; in other words, social interaction appeals to tourists' emotions during their stay in this natural park. Those emotions emerge as tourists get together, exchange ideas, opinions, experiences, and get to know the local population. For example, on a tour to a natural park, visitors try to get involved with the community and socialize with fellow travelers. Thus, the emotional and the social factor emerges within the perceived value and influences the future behavior of the tourist.

The second objective of the present study analyzed the dimensions of perceived value predicting satisfaction in ecotourism. The functional value was found as the most salient predictor of satisfaction in ecotourism. These findings are consistent with the current literature. For example, Kim and Park [28] found that the functional, social, and emotional dimensions positively affected overall satisfaction, similar to the "functional" value identified in our study. Additionally, Lee et al. [38] established that functional, general, and emotional values positively influenced tourist satisfaction, coinciding with our "functional" value. For Carvache-Franco et al. [36], the functional and emotional values were related to satisfaction, aligning with our results, as well. In contrast, Kim and Thapa [35] established emotional and social values as the only dimensions of satisfaction, which differ from the present findings.

These results shed light on this topic by identifying the "functional" dimension as the perceived value that primarily predicts general satisfaction. Therefore, tourists will be more satisfied if the products and services in this type of protected area are functional; that is, well organized and efficient in terms of adequate infrastructure and trained personnel.

Identifying the dimensions of perceived value predicting ecotourists' intentions to return, recommend, and provide positive word of mouth about the ecotourism destination 
as loyalty variables was the third objective of the research. In this line, several studies have found that perceived value influences the intentions to revisit a destination $[18,40,49,50]$. However, the scientific literature has not identified which dimension of perceived value is the most significant predictor of the intentions to return, recommend, and provide positive word of mouth about an ecotourism destination.

As a contribution to the literature, the findings of this study show the "functional" dimension as the most significant predictor of tourists' intentions to return to this type of protected area. Therefore, these destinations must offer well-organized and efficient products and services to increase tourists' revisit intentions. In this way, the planning and offering of services should be improved, well organized, and comfortable, with adequate infrastructure and trained personnel.

This study sheds light on this topic by identifying that tourists will recommend these destinations if they experience products and services in a good social and emotional environment. Thus, services that include group meetings and events should be improved, giving tourists the chance to meet and interact with each other. Likewise, this research contributes to the existing literature by establishing the relevance of well-organized and efficient products and services, with an excellent atmosphere and reasonable prices for tourists to speak positively of these destinations with other travelers.

In this way, destinations must provide organized services, adequate infrastructure, and staff that offer tourists fun times and meaningful experiences with each other. They could also offer reasonable prices according to the quality of the products. In this way, tourists will provide positive word of mouth about the destination to their friends and acquaintances, increasing new visits and benefiting these destinations and the community.

\section{Theoretical and Practical Implications}

Among the theoretical implications, this study contributes to the literature by adding three perceived values in ecotourism, consistent with previous research $[22,23,28,35,36,38]$. Furthermore, finding the social and emotional value together in a single dimension demonstrates that the social environment provides an emotional experience to tourists. This means that visitors' emotions are related to interacting with other tourists and the local population.

This study also identified "functional value" as the main predictor of return intentions in ecotourism, which sheds light on this scarcely researched topic. The "functional" value was also established as the most salient predictor of satisfaction. Similar results have been found in previous research $[28,35,36]$. Both the "Functional" and the "Social and emotional" dimensions are important predictors of tourists' intentions to recommend these types of destinations. Additionally, the three values (functional, social and emotional, and economic) significantly predict tourists' willingness to provide positive word of mouth about these protected areas.

Among the practical implications, the perceived value helps tourism companies know the value visitors give to their services. This variable can also guide companies to set the prices and quality of their services. Therefore, it is crucial to analyze the economic value that tourists perceive to offer them services at reasonable prices correlated with their quality.

The perceived value also helps companies increase the effectiveness of strategic actions by providing products with the "functional" value that tourists expect to receive. Thus, it is essential to have well-planned services in terms of materials, personnel, and infrastructure, making visitors feel in a pleasant environment, with comfortable furniture and facilities, and well cared for by trained personnel willing to offer timely service. In this way, tourists satisfaction and return to these protected areas can increase, bringing benefits to the destination and the community and contributing to the conservation of the environment and the sustainability of these sites.

Likewise, it is essential to improve the social and emotional environment when offering services in these destinations. This can be done by organizing groups, events, and meetings so that tourists can interact, get to know each other, exchange opinions and 
experiences, and have fun together, giving them an exciting experience. This study can contribute to the planning of public policies to increase tourists' loyalty, taking into account environmental conservation and sustainability in these protected areas.

\section{Conclusions}

Ecotourism is a type of tourism where visitors can carry out activities related to nature while respecting the environment. Protected areas are one of the most visited ecotourism destinations. Therefore, it is important to carry out studies of perceived value in these places to contribute to the development of public policies and the execution of sustainable programs within protected areas.

Studying the perceived value in ecotourism is crucial to generalize results and contribute to the literature on this subject. In ecotourism, the perceived value is a multidimensional construct that evaluates economic and cognitive aspects, predicting the behavior of visitors to protected areas concerning satisfaction and loyalty. Therefore, this study offers relevant information to create guides of action for sustainable plans.

This research found three dimensions of perceived value in ecotourism destinations, namely, functional, economic, and social and emotional. The most salient dimension was "economic value." Therefore, it is essential to offer reasonably priced quality services in these protected areas to increase tourists' perceived value. Moreover, the "functional" dimension was the most influential predictor of tourists' satisfaction, intention to revisit and to provide positive word of mouth. Thus, the organization and efficiency of products and services should be improved to increase visitor's satisfaction and return to these destinations. Likewise, the "functional" and the "social and emotional" dimensions were identified as significant predictors of tourists' intentions to recommend these places. Therefore, it is necessary to have destinations with a good social environment, where tourists can experience emotions while interacting with each other and the local population. In this way, the intentions of recommending these sites could increase. It is also necessary to improve the three perceived values found (functional, economic, and social and emotional) to encourage tourists to provide positive word of mouth about the destination to other visitors.

\section{Limitations and Future Investigations}

Despite these significant findings, this study needs to acknowledge its main limitations. Since the survey was conducted from August to September, the results may be limited by seasonal effects, considering that the demand can vary in other seasons. Another limitation is having used a questionnaire adapted from an ecotourism study that found dimensions of perceived value similar to the present study. However, new contributions to the academic literature were found when applied to a different destination. Finally, future research should address the perceived value and image in ecotourism destinations in post-COVID-19 tourism.

Author Contributions: Conceptualization, C.C.-L., M.C.-F. and W.C.-F.; methodology, C.C.-L. and M.C.-F.; software, C.C.-L. and M.C.-F.; validation, C.C.-L. and M.C.-F.; formal analysis, C.C.-L. and M.C.-F.; investigation, C.C.-L., M.C.-F. and W.C.-F.; resources, C.C.-L., M.C.-F. and W.C.-F.; data curation, C.C.-L. and M.C.-F.; writing-original draft preparation, C.C.-L., M.C.-F. and W.C.F.; writing-review and editing, C.C.-L., M.C.-F. and W.C.-F.; visualization, C.C.-L. and M.C.-F.; supervision, C.C.-L.; project administration, C.C.-L. All authors have read and agreed to the published version of the manuscript.

Funding: This research received no external funding.

Institutional Review Board Statement: Not applicable.

Informed Consent Statement: Not applicable.

Data Availability Statement: Not applicable.

Conflicts of Interest: The authors declare no conflict of interest. 


\section{References}

1. Choi, Y.E.; Oh, C.-O.; Chon, J. Applying the resilience principles for sustainable ecotourism development: A case study of the Nakdong Estuary, South Korea. Tour. Manag. 2021, 83, 104237. [CrossRef]

2. Hultman, M.; Skarmeas, D.; Oghazi, P.; Beheshti, H.M. Achieving tourist loyalty through destination personality, satisfaction, and identification. J. Bus. Res. 2015, 68, 2227-2231. [CrossRef]

3. Cheng, T.-M.; Wu, H. How do environmental knowledge, environmental sensitivity, and place attachment affect environmentally responsible behavior? An integrated approach for sustainable island tourism. J. Sustain. Tour. 2015, 23, 557-576. [CrossRef]

4. Wondirad, A.; Tolkach, D.; King, B. Stakeholder collaboration as a major factor for sustainable ecotourism development in developing countries. Tour. Manag. 2020, 78, 104024. [CrossRef]

5. Fletcher, R. Ecotourism after nature: Anthropocene tourism as a new capitalist "fix". J. Sustain. Tour. 2019, 27, 522-535. [CrossRef]

6. Si-Shyun, L.J. The moderating role of intercultural service encounters in the relationship among tourist's destination image, perceived value and environmentally responsible behaviors. Am. J. Tour. Manag. 2018, 7, 1-9. [CrossRef]

7. Briassoulis, H.; Van Der Straaten, J. (Eds.) Tourism and the Environment: Regional, Economic, Cultural and Policy Issues; Springer Science \& Business Media: Berlin/Heidelberg, Germany, 2013; Volume 6.

8. Handriana, T.; Ambara, R. Responsible environmental behavior intention of travelers on ecotourism sites. Tour. Hosp. Manag. 2016, 22, 135-150. [CrossRef]

9. Dowling, R.K. Book Review: Critical Issues in Ecotourism: Understanding a Complex Tourism Phenomenon, Edited by James Higham. Int. J. Tour. Policy 2007, 1, 286. [CrossRef]

10. Honey, M. Ecotourism and Sustainable Development: Who Owns Paradise? 2nd ed.; Island Press: Washington, DC, USA, 2008.

11. Beall, J.M.; Boley, B.B.; Landon, A.C.; Woosnam, K.M. What drives ecotourism: Environmental values or symbolic conspicuous consumption? J. Sustain. Tour. 2021, 29, 1215-1234. [CrossRef]

12. Osman, T.; Shaw, D.; Kenawy, E. Examining the extent to which stakeholder collaboration during ecotourism planning processes could be applied within an Egyptian context. Land Use Policy 2018, 78, 126-137. [CrossRef]

13. Jones, S. Community-Based Ecotourism: The Significance of Social Capital. Ann. Tour. Res. 2005, 32, 303-324. [CrossRef]

14. Liu, J.; Qu, H.; Huang, D.; Chen, G.; Yue, X.; Zhao, X.; Liang, Z. The role of social capital in encouraging residents' proenvironmental behaviors in community-based ecotourism. Tour. Manag. 2014, 41, 190-201. [CrossRef]

15. Reimer, J.K.; Walter, P. How do you know it when you see it? Community-Based ecotourism in the Cardamom Mountains of southwestern Cambodia. Tour. Manag. 2013, 34, 122-132. [CrossRef]

16. Ketema, T.D. Development of Community based Ecotourism in Wenchi Crater Lake, Ethiopia: Challenges and Prospects. J. Hosp. Manag. Tour. 2015, 6, 39-46. Available online: http:/ / www.academicjournals.org/JHMT (accessed on 2 May 2021).

17. Thapa, B.; Lee, J. Visitor experience in Kafue National Park, Zambia. J. Ecotourism 2016, 16, 112-130. [CrossRef]

18. Chiu, Y.-T.H.; Lee, W.-I.; Chen, T.-H. Environmentally Responsible Behavior in Ecotourism: Exploring the Role of Destination Image and Value Perception. Asia Pac. J. Tour. Res. 2014, 19, 876-889. [CrossRef]

19. Cronin, J.; Brady, M.K.; Hult, G.T.M. Assessing the effects of quality, value, and customer satisfaction on consumer behavioral intentions in service environments. J. Retail. 2000, 76, 193-218. [CrossRef]

20. Grewal, D.; Monroe, K.B.; Krishnan, R. The Effects of Price-Comparison Advertising on Buyers' Perceptions of Acquisition Value, Transaction Value, and Behavioral Intentions. J. Mark. 1998, 62, 46. [CrossRef]

21. Jamal, A.; Sharifuddin, J. Perceived value and perceived usefulness of halal labeling: The role of religion and culture. J. Bus. Res. 2015, 68, 933-941. [CrossRef]

22. Williams, P.; Soutar, G. Value, Satisfaction and Behavioral Intentions in an Adventure Tourism Context. Ann. Tour. Res. 2009, 36, 413-438. [CrossRef]

23. Lee, J.; Lee, C.-K.; Choi, Y. Examining the Role of Emotional and Functional Values in Festival Evaluation. J. Travel Res. 2010, 50, 685-696. [CrossRef]

24. Schoeman, K.; Van der Merwe, P.; Slabbert, E. The Perceived Value of a Scuba Diving Experience. J. Coast. Res. 2016, 321, 1071-1080. [CrossRef]

25. Um, J.; Yoon, S. Evaluating the relationship between perceived value regarding tourism gentrification experience, attitude, and responsible tourism intention. J. Tour. Cult. Chang. 2020, 1-17. [CrossRef]

26. Eid, R.; El-Gohary, H. The role of Islamic religiosity on the relationship between perceived value and tourist satisfaction. Tour. Manag. 2015, 46, 477-488. [CrossRef]

27. Bajs, I.P. Tourist Perceived Value, Relationship to Satisfaction, and Behavioral Intentions. J. Travel Res. 2013, 54, 122-134. [CrossRef]

28. Kim, K.-H.; Park, D.-B. Relationships Among Perceived Value, Satisfaction, and Loyalty: Community-Based Ecotourism in Korea. J. Travel Tour. Mark. 2017, 34, 171-191. [CrossRef]

29. Petrick, J.F. Development of a Multi-Dimensional Scale for Measuring the Perceived Value of a Service. J. Leis. Res. 2002, 34, 119-134. [CrossRef]

30. Sánchez-Fernández, R.; Iniesta-Bonillo, M.Á. Efficiency and quality as economic dimensions of perceived value: Conceptualization, measurement, and effect on satisfaction. J. Retail. Consum. Serv. 2009, 16, 425-433. [CrossRef]

31. Chi, T.; Kilduff, P.P. Understanding consumer perceived value of casual sportswear: An empirical study. J. Retail. Consum. Serv. 2011, 18, 422-429. [CrossRef] 
32. Koller, M.; Floh, A.; Zauner, A. Further insights into perceived value and consumer loyalty: A "green" perspective. Psychol. Mark. 2011, 28, 1154-1176. [CrossRef]

33. Lee, C.-K.; Bendle, L.J.; Yoon, Y.-S.; Kim, M.-J. Thanatourism or peace tourism: Perceived value at a North Korean resort from an indigenous perspective. Int. J. Tour. Res. 2011, 14, 71-90. [CrossRef]

34. Jamal, S.A.; Othman, N.; Muhammad, N.M.N. Tourist perceived value in a community-based homestay visit: An investigation into the functional and experiential aspect of value. J. Vacat. Mark. 2011, 17, 5-15. [CrossRef]

35. Kim, M.; Thapa, B. Perceived value and flow experience: Application in a nature-based tourism context. J. Destin. Mark. Manag. 2018, 8, 373-384. [CrossRef]

36. Carvache-Franco, M.; Carvache-Franco, O.; Solis-Radilla, M.M.; Carvache-Franco, W. The perceived value and profile of protected areas visitors: A case study of the Guayas province, Ecuador. Geogr. Pannonica 2019, 23, 135-147. [CrossRef]

37. Carvache-Franco, M.; Perez-Orozco, A.; Carvache-Franco, O.; Víquez-Paniagua, A.G.; Carvache-Franco, W. The perceived value in ecotourism related to satisfaction and loyalty: A study from Costa Rica. Geogr. Pannonica 2020, 24, 229-243. [CrossRef]

38. Lee, C.-K.; Yoon, Y.-S.; Lee, S.-K. Investigating the relationships among perceived value, satisfaction, and recommendations: The case of the Korean DMZ. Tour. Manag. 2007, 28, 204-214. [CrossRef]

39. Ha, J.; Jang, S.S. Perceived values, satisfaction, and behavioral intentions: The role of familiarity in Korean restaurants. Int. J. Hosp. Manag. 2010, 29, 2-13. [CrossRef]

40. Peña, A.P.; Jamilena, D.M.F.; Molina, M.A.R. The perceived value of the rural tourism stay and its effect on rural tourist behaviour. J. Sustain. Tour. 2012, 20, 1045-1065. [CrossRef]

41. Jin, N.; Lee, S.; Lee, H. The Effect of Experience Quality on Perceived Value, Satisfaction, Image and Behavioral Intention of Water Park Patrons: New versus Repeat Visitors. Int. J. Tour. Res. 2015, 17, 82-95. [CrossRef]

42. Oviedo-García, M.Á.; Castellanos-Verdugo, M.; Vega-Vázquez, M.; Orgaz-Agüera, F. The Mediating Roles of the Overall Perceived Value of the Ecotourism Site and Attitudes Towards Ecotourism in Sustainability Through the Key Relationship Ecotourism Knowledge-Ecotourist Satisfaction. Int. J. Tour. Res. 2017, 19, 203-213. [CrossRef]

43. Li, J. Impact of tourists' perceived value on brand loyalty: A case study of Xixi National Wetland Park. Asia Pac. J. Tour. Res. 2021, 26, 262-276. [CrossRef]

44. Chua, B.-L.; Lee, S.; Goh, B.; Han, H. Impacts of cruise service quality and price on vacationers' cruise experience: Moderating role of price sensitivity. Int. J. Hosp. Manag. 2015, 44, 131-145. [CrossRef]

45. Kim, H.; Woo, E.; Uysal, M. Tourism experience and quality of life among elderly tourists. Tour. Manag. 2015, 46, 465-476. [CrossRef]

46. Baloglu, S. An Investigation of a Loyalty Typology and the Multidestination Loyalty of International Travelers. Tour. Anal. 2001, 6, 41-52. [CrossRef]

47. Iwasaki, Y.; Havitz, M.E. A Path Analytic Model of the Relationships between Involvement, Psychological Commitment, and Loyalty. J. Leis. Res. 1998, 30, 256-280. [CrossRef]

48. Yoon, Y.; Uysal, M. An examination of the effects of motivation and satisfaction on destination loyalty: A structural model. Tour. Manag. 2005, 26, 45-56. [CrossRef]

49. Oliver, R.L. Satisfaction: A Behavioral Perspective on the Consumer: A Behavioral Perspective on the Consumer; Routledge: London, UK, 2014. Available online: https:/ / doc1.bibliothek.li/acb/FLMF040180.pdf (accessed on 2 May 2021).

50. Chen, C.-F.; Chen, F.-S. Experience quality, perceived value, satisfaction and behavioral intentions for heritage tourists. Tour. Manag. 2010, 31, 29-35. [CrossRef]

51. Government of Aragon, 2021. Posets-Maladeta Natural Park. Available online: https://www.aragon.es/-/parque-natural-deposets-maladeta (accessed on 2 May 2021).

52. Lee, T.H.; Jan, F.-H.; Tseng, C.H.; Lin, Y.F. Segmentation by Recreation Experience in Island-Based Tourism: A Case Study of Taiwan's Liuqiu Island. J. Sustain. Tour. 2018, 26, 362-378. [CrossRef] 